\title{
PELAKSANAAN EVALUASI AFEKTIF PADA MATA PELAJARAN PAI DI SMA NEGERI 2 RAMBATAN
}

\author{
Yeni Eka Putri \\ Guru SD Negeri 32 Koto Panjang Sei. Tarab \\ e-mail: yeni.eka.putri@yahoo.com
}

\begin{abstract}
The study was purposed at explaining the affective evaluation and the obtacle on Islamic Education in State High School 2 Rambatan. This study used qualitative research method by applying observation, interview and documentation. Data were analyzed by using triangulation. The result of the study showed that the affective evaluation on Islamic Education got problem on conceptual and operational. The conceptual problem was difficult on applying the guidelines on the affective evaluation domain of the government and the Ministry of Religious Affairs. For the operational issue that the affective evaluation needs a lot of time, it pertains to feelings of students, and no cooperation in affective evaluation.
\end{abstract}

Keywords: Affective Evaluation, Islamic Education, High School, Rambatan

\section{PENDAHULUAN}

SMA Negeri 2 Rambatan merupakan salah satu sekolah favorit yang setiap tahunnya jumlah siswa yang masuk semakin meningkat (Hasil Wawancara dengan Kepala Sekolah SMA Negeri 2 Rambatan, 17 Desember 2015). Posisi sekolah yang terletak di perbatasan dua kabupaten ini menjadikan sekolahnya memiliki daya tarik tersendiri untuk menarik banyak siswa memasukinya, apalagi lokasi sekolah ini juga terletak di dekat danau terbesar di Sumatera Barat, Danau Singkarak. Namun yang terpenting, prestasi sekolah ini telah terbukti di berbagai event, seperti liga sepakbola, kegiatan keagaman dan olimpiade berbagai mata pelajaran, seperti matematika, dan IPA. SMA Negeri 2 Rambatan juga memiliki prestasi dalam pembelajaran, di mana pada hasil Ujian Nasional sekolah ini selalu menduduki lima besar di tingkat kabupaten selama beberapa tahun terakhir.

Melihat berbagai prestasi tersebut menurut peneliti perlu diketahui bagaimana pelaksanaan evaluasi pembelajarannya. Karena untuk mengetahui hasil pembelajaran ataupun prestasi yang baik tentu dengan pelaksanaan proses evaluasi yang baik pula. 
Dalam penelitian ini yang dilihat adalah pelaksanaan evaluasi ranah afektif pada mata pelajaran Pendidikan Agama Islam (PAI), karena ranah afektif merupakan salah satu aspek penilaian dalam pembelajaran yang sering kali terkesampingkan. Hal ini bisa disebabkan oleh tuntutan kurikulum yang lebih dominan pada aspek kognitif ataupun ketidakmampuan guru dalam menerapkannya di dalam pembelajaran.

Dari proses pelaksanaan evaluasi ranah afektif mata pelajaran PAI di SMA Negeri 2 Rambatan terdapat beberapa masalah yang menjadi perhatian peneliti, yaitu penerapan rambu-rambu evaluasi ranah afektif dari pemerintah dan dari Departemen Agama oleh guru (Hasil Wawancara dengan Guru PAI SMA Negeri 2 Rambatan, 17 Desember 2015). Hal ini terlihat dari beberapa soal ulangan akhir semester maupun dalam Ujian Nasional kebanyakan didominasi oleh aspek kognitif. Selain itu evaluasi memerlukaan banyak waktu, dan evaluasi afektif termasuk sulit karena berkaitan dengan perasaan siswa, dan tidak adanya kerja sama dalam pelaksanaan evaluasi afektif (Hasil Wawancara dengan guru PAI SMA Negeri 2 Rambatan, 17 Desember 2015). Waktu yang diperlukan untuk kegiatan evaluasi afektif tergolong banyak, karena untuk mewawancarai siswa satu persatu butuh satu jam pelajaran. Berdasarkan fenomena tersebut, menurut peneliti kajian tentang pelaksanaan evaluasi ranah afektif pada mata pelajaran PAI di SMA Negeri 2 Rambatan penting dilakukan.

\section{PENGUKURAN, PENILAIAN DAN EVALUASI}

Print (1993) menyatakan bahwa pengukuran "...concerned with the statement of performance usually represented in quantitavive terms". Lovat and Smith menyatakan, pengukuran adalah "...concerned with gathering information about what people think, feel and can do ... often, measurement uses a numerical score". Pendapat yang hampir sama menurut Miller et. al. (2009), dan Gronlund dan Linn (1990), "measurement is the assigning of numbers to the results of a test or other type of assessment according to a spesific rule (e.g., accounting correct answer or awarding points for particular aspects of an essay)". Jadi, pengukuran adalah 1) pemberian atribut kepada objek berupa angka atau skor; 2) proses pengumpulan data untuk mengukur capaian kinerja atau performance seseorang; dan 3) proses untuk menentukan dan membedakan satu objek dengan objek lainnya (Arikunto, 2013; Arifin, 2012).

Penilaian menurut Print (1993) adalah “...essentially concerned with firstly making sense out of measurement data and and assigning a mark, a grade, a rank or some form of qualitative comment". Gronlund dan Linn 
(1990) mendefinisikan penilaian sebagai suatu proses yang sistematis dan mencakup kegiatan mengumpulkan, menganalisis, serta menginterpretasikan informasi untuk menentukan seberapa jauh seorang siswa atau sekelompok siswa mencapai tujuan pembelajaran yang telah ditetapkan, baik aspek pengetahuan, sikap maupun keterampilan. Sudijono (2011) mengatakan, menilai mengandung arti mengambil keputusan terhadap sesuatu berdasar atau berpegang pada ukuran baik atau buruk, sehat atau sakit, pandai atau bodoh dll. Jadi, penilaian merupakan kegiatan yang dilakukan sistematis dan terencana sebagai usaha mengumpulkan data dan kemudian menganalisanya untuk dibuat penomoran, kelas dan perankingan.

Worthen dkk (1987) menjelaskan "evaluation uses inquiry and judgement methods including determining standars for judging quality and deciding whether those standards should be relative or absolute". Kemudian Print (1983) menyatakan "...with the information gained from measurement and assessment, educators are in a better position to make value judgement which are invariably expressed as written comments". Lalu Lovat (2003) mengemukakan "evaluation is the overarching concept which both depends upon measurements and assessment to make a composite judgment or desicion". Jadi, evaluasi merupakan kegiatan yang lebih kompleks dibandingkan dengan pengukuran dan penilaian. Evaluasi merupakan kegiatan yang sangat sistematis yang mencakup pengukuran dan penilaian yang di dalamnya terdapat aspek pertimbangan dan keputusan kepada suatu program berdasarkan standar atau kriteria yang telah ditetapkan sebelum program tersebut berjalan.

\section{RANAH AFEKTIF}

Aspek afektif merupakan aspek pembelajaran yang tidak dapat terpisahkan dengan kedua aspek lainnya, yaitu aspek kognitif dan psikomotor baik di dalam proses pembelajaran maupun evaluasinya (Fernandes, 1983). Menurut Anderson \& Krathwol (2010) aspek afektif terbagi menjadi lima tingkatan. Konsep afektif didefinisikan dalam hubungan hirarkhi internalisasi. Dari peringkat yang paling sederhana yakni sadar akan konsep (penerimaan) sampai yang kompleks yang dikarakterisasikan dengan memiliki dan mengembangkan nilai baru (karakterisasi). Hirarkhi afektif yaitu receiving, responding, valuing, organizing dan characterizing by value.

Sudijono (1996) menjelaskan bahwa receiving adalah kepekaan seseorang dalam menerima rangsangan atau stimulus dari luar yang datang kepada dirinya dalam bentuk masalah, situasi gejala dan lainlain. Responding mengandung arti adanya 
partisipasi aktif. Valuing, menilai atau menghargai berarti memberikan nilai atau memberikan penghargaan terhadap auatu kegiatan atau obyek, sehingga apabila kegiatan itu tidak dikerjakan, dirasakan akan membawa kerugian atau penyesalan. Organizing artinya pengembangan dari nilai kedalam satu system organisasi termasuk di dalamnya hubungan satu nilai dengan nilai lain, pemantapan dan prioritas nilai yang dimilikinya.

Characterizing by value yaitu keterpaduan semua system nilai yang telah dimiliki seseorang yang mempengaruhi pola kepribadian dan tingkah lakunya. Di sini proses internalisasi nilai telah menempati tempat tertingggi dalam suatu hirarkhi nilai. Nilai itu telah tertanam secara konsisten dan telah mempengaruhi emosinya. Pada jenjang ini peserta didik telah memiliki system nilai yang mengontrol tingkah lakunya untuk suatu waktu yang cukup lama sehingga membentuk karakteristik "pola hidup" tingkah lakunya menetap, konsisten dan dapat diramalkan. Tahapan evaluasi ranah kognitif meliputi perencanaan, pelaksanaan, dan analisis evaluasi ranah kognitif.

\section{PENDIDIKAN AGAMA ISLAM}

Pendididikan Agama Islam dimaksudkan untuk meningkatkan potensi spiritual dan membentuk peserta didik agar menjadi manusia yang beriman dan bertaqwa kepada Tuhan Yang Mahas Esa dan berakhlak mulia. Akhlak mencakup etika,budi pekerti, dan moral sebagai perwujudan dari pendidikan Agama. "Peningkatan Spritual mencakup pengenalan, pemahaman, dan penanaman nilai-nilai keagamaan, serta pengamalan nilainilai tersebut dalam kehidupan individual ataupun kolektif kemasyarakatanya yang bertujuan pada optimalisasi berbagai potensi spiritual dimiliki manusia yang aktuliasasinya mencerminkan harkat dan martabatnya sebagai makhluk Tuhan” (BSNP, 2006).

Pendidikan Agama Islam diberikan dengan mengikuti tuntunan bahwa agama diajarkan manusia mempunyai visi untuk mewujudkan manusia yang bertaqwa kepada Allah SWT dan berakhlak mulia, serta bertujuan untuk menghasilkan manusia yang jujur, adil, berbudi pekerti, etis, saling menghargai, disiplin, harmonis dan produktif baik personal maupu sosial. Tuntunan visi ini mendorong dikembangkanya standar kompetensi sesuai dengan jenjang pesekolahan yang ditandai dengan ciriciri (a) lebih menitik beratkan pencapaian kompetensi secara utuh selain pengusaan materi, (b) mengakomodasikan keragaman kebutuhan dan sumber daya pendidikan yang tersedia, dan (c) memberikan kebebasan yang lebih luas kepada pendidik di lapangan untuk mengembangkan strategi dan program 
pembelajaran sesuai dengan kebutuhan dan ketersediaan sember daya pendidikan.

Ruang lingkup Pendidikan Agama Islam menekankan keseimbangan, keselarasan, dan keserasian antara Hubungan manusia dengan Allah SWT, Hubungan manusia dengan sesama manusia, Hubungan manusia dengan diri sendiri, dan Hubungan manusia dengan alam. Ruang lingkup Pendidikan Agama Islam yaitu Al-Qur'an dan Hadits, Aqidah, Akhlak, Fiqih, Tarikh dan Kebudayaan Islam (BSNP, 2006).

\section{METODE PENELITIAN}

Jenis penelitian ini merupakan penelitian deskriptitf kualitatif yaitu penelitian tentang data yang dikumpulkan dan dinyatakan dalam bentuk kata-kata. Kata-kata disusun dalam kalimat, misalnya kalimat hasil wawancara antara peneliti dan informan (Beni, 2008). penelitian ini menggunakan pendekatan kualitatif, berusaha mendapatkan informasi yang selengkap mungkin mengenai pelaksanaan evaluasi ranah afektif di SMA Negeri 2 Rambatan. Teknik pengumpulan data yang digunakan adalah dengan observasi, wawancara dan dokumentasi.

Tahap-tahap dalam pengumpulan data dalam penelitian ini, yaitu "tahap orientasi, tahap ekplorasi dan tahap member chek. Tahap orientasi, dalam tahap ini yang dilakukan peneliti adalah melakukan prasurvey ke lokasi yang akan diteliti, dalam penelitian ini, prasurvey dilakukan di SMA Negeri 2 Rambatan berbentuk dialog dengan kepala sekolah, beberapa perwakilan guru, juga dari karyawan dan peserta didik. Kemudian peneliti juga melakukan studi dokumentasi serta kepustakaan untuk melihat dan mencatat data-data yang diperlukan dalam penelitian ini. Tahap eksplorasi, tahap ini merupakan tahap pengumpulan data di lokasi penelitian, dengan melakukan wawancara dengan unsur-unsur yang terkait, dengan pedoman wawancara yang telah disediakan peneliti, dan melakukan observasi tidak langsung tentang kondisi sekolah dan mengadakan pengamatan langsung tentang pelaksanaan evaluasi ranah kognitif pada mata pelajaran PAI di sekolah itu. Tahap member chek, setelah data diperoleh di lapangan, baik melalui observasi, wawancara ataupun studi dokumentasi, peneliti memeriksa keabsahan data sesuai dengan sumber aslinya (Zariah, 2005).

Manurut Patton (1990) teknik analisis data adalah "proses kategori urutan data, mengorganisasikannya ke dalam suatu pola, kategori dan satuan uraian dasar, ia membedakannya dengan penafsiran yaitu memberikan arti yang signifikan terhadap analisis, menjelaskan pola uraian dan mencari 
hubungan di antara dimensi-dimensi uraian". Analisis data dimulai dengan menelaah seluruh data yang tersedia dari berbagai sumber, yaitu wawancara, pengamatan yang sudah dituliskan dalam catatan lapangan, dokumen pribadi, dokumen resmi, gambar, foto, dan sebagainya. Setelah dibaca, dipelajari, dan ditelaah, langkah berikutnya ialah mengadakan reduksi data yang dilakukan dengan jalan rangkuman yang inti, proses dengan pernyataan-pernyataan yang perlu dijaga sehingga tetap berada di dalamnya. Dalam menguji keabsahan data, peneliti menggunakan teknik trianggulasi, yaitu pemeriksaan keabsahan data yang memanfaatkan sesuatu yang lain di luar data untuk keperluan pengecekan atau sebagai pembanding terhadap data tersebut.

\section{HASIL PENELITIAN DAN PEMBAHASAN}

Dalam rumusan tujuan dari pelaksanaan evaluasi ranah afektif mata pelajaran PAI di SMA Negeri 2 Rambatan disesuaikan dengan mata pelajaran yang sudah diajarkan pada semester tersebut. Tujuan ini hanya mengarah pada sikap berperilaku dan kegiatan keagamaan sehari-hari di sekolah, sehingga untuk pelaksanaannya hanya bisa dilakukan dengan cara pengamatan secara langsung dan penggunaan skala sikap (Hasil Wawancara dengan Guru PAI SMA Negeri 2 Rambatan, 18 Desember 2015). Waktu pelaksanaan evaluasi afektif mata pelajaran PAI di SMA Negeri 2 Rambatan dilakukan tidak setiap hari, akan tetapi dilakukan ketika guru berada di dalam kelas untuk menyampaikan pelajaran, jadi guru tidak hanya menyampaikan pelajaran tetapi juga melakukan evaluasi, dan evaluasi ini juga dilakukan ketika guru berinteraksi langsung dengan siswa (Hasil Wawancara dengan Guru PAI SMA Negeri 2 Rambatan, 18 Desember 2015).

Dalam pelaksanaan observasi untuk menilai aspek perilaku yang dilakukan guru PAI belum direncanakan sebelumnya, sehingga untuk pelaksanaannya kurang baik. Pelaksanaannya sudah bagus, akan tetapi sebaiknya proses pengamatan secara langsung direncanakan sebelumnya, guru harus membawa catatan khusus untuk mencatat perilaku siswa yang muncul secara tiba- tiba, karena kalau hanya dengan mengingat saja, dikhawatirkan akan lupa. Dari penerapan observasi secara langsung di atas, pelaksanaannya belum sesuai dengan buku pedoman standar penilaian dari Departemen Agama (Hasil Observasi di SMA Negeri 2 Rambatan, 18 Desember 2015).

Teknik evaluasi afektif dengan wawancara langsung di SMA Negeri 2 Rambatan ini diberikan kepada siswa yang melanggar atau melakukan kasus tertentu di sekolah. Teknik wawancara yang digunakan adalah 
wawancara bebas, sehingga guru dapat memberikan pertanyaan sendiri tanpa harus mengacu pada pedoman wawancara (Hasil Observasi di SMA Negeri 2 Rambatan, 18 Desember 2015). Wawancara langsung ini hanya dilakukan terhadap siswa yang mempunyai kasus tertentu, seperti melanggar tata tertib sekolah dan tidak melakukan shalat berjamaah (Observasi di SMA Negeri 2 Rambatan, 18 Desember 2015). Hal ini dilakukan karena guru tidak terlalu mementingkan penilaian afektif dengan cara wawancara lansung, karena akan menyita banyak waktu, padahal sebenarnya tidak, asalkan guru dapat mengaturnya dengan baik. Jadi untuk teknik evaluasi wawancara jarang sekali diterapkan. Seharusnya teknik wawancara ini tidak hanya dilakukan terhadap siswa yang mengalami kasus tertentu, akan tetapi dilakukan juga terhadap seluruh siswa. Topik wawancara bisa mengenai mata pelajaran PAI, misalkan tentang shalat, bagaimana hikmah shalat yang siswa rasakan setelah rajin melaksanakannya setip hari. Bisa juga mengenai konsep diri yang dimiliki siswa atau tentang kehidupan sosial siswa. Sehingga siswa dapat menerapkan hasil belajarnya dalam kehidupan sehari-hari.

Teknik evaluasi afektif yang dilakukan di SMA Negeri 2 Rambatan adalah teknik Skala Likert. (Dokumentasi di SMA Negeri
2 Rambatan, 18 Desember 2015). Teknik ini dibuat oleh guru PAI sendiri, dan ternyata sudah bagus, karena model skalanya atas inisiatif guru sendiri dan isi dari pernyataanpernyataan yang ada sudah mengacu pada indikator hasil belajar mata pelajaran PAI, yaitu Al-Qur'an, Akidah, Fiqh, Sejarah dan Syari’ah.

Setiap butir pernyataan yang terdapat dalam skala tersebut juga berisi tentang perilaku, kebiasaan keagamaan dan kepribadian sebagai aplikasi dari hasil pembelajaran PAI. Selain itu guru juga memberikan rentangan skala menggunakan tiga pilihan yaitu selalu, kadang-kadang dan jarang. Jadi, siswa tidak hanya memberikan tanda chek list, tetapi siswa diharuskan untuk memberikan keterangan mengapa siswa memilih salah satu jawaban, sehingga dengan cara ini dapat diketahui sikap dan perilaku siswa yang sebenarnya (Dokumentasi di SMA Negeri 2 Rambatan, 18 Desember 2015).

Aspek yang dinilai dalam mengevaluasi ranah afektif mata pelajaran PAI yaitu sikap, dan prilaku keagamaan. Sikap merupakan reaksi yang disebabkan adanya rangsangan yang datang dari luar. Dari beberapa sikap yang ada, yang banyak dievaluasi adalah ketika dalam proses belajar mengajar yaitu sikap terhadap mata pelajaran, guru dan proses belajar mengajar itu sendiri. Sikapsikap tersebut harus menjadi prioritas guru dalam melakukan evaluasi afektif, karena 
sikap yang ditimbulkan oleh siswa baik atau buruk akan berimbas pada kebiasaaannya di dalam kelas yang juga akan berdampak ketika siswa berada di rumah (Observasi di SMA Negeri 2 Rambatan, 18 Desember 2015).

Penilaian terhadap perilaku keagamaan ini bertujuan untuk membentuk kebiasaan siswa dalam melaksanakan kegiatan keagamaan yang dilakukan setiap hari. Kebiasaan keagamaan ini yaitu melaksanakan rutinitas pagi seperti shalat dhuha berjamaah dan mujahadah asmaul khusna sebelum masuk kelas, pembacaan surat-surat pendek yang dipandu oleh wali kelas, shalat dzuhur berjamaah atau shalat jum'at berjamaah bagi siswa laki-laki dan shalat ashar berjamaah (Observasi di SMA Negeri 2 Rambatan, 18 Desember 2015).

Ada dua macam dalam pelakanaan evaluasi ranah afektif di SMA Negeri 2 Rambatan, yaitu evaluasi proses dan evaluasi hasil belajar. Pada evaluasi proses, permasalahan dalam proses pembelajaran selalu mewarnai jalannya proses pembelajaran, contohnya seperti berbicara dengan temannya sendiri dengan posisi duduk menghadap kesamping, hal ini dapat mengganggu jalannya pembelajaran, lalu guru menasehatinya untuk tidak mengganggu proses pembelajaran dengan berbicara sendiri. Untuk kerapian pakaian setiap siswa diperhatikan karena dari cara berpakaian akan terlihat bagaimana tingkah laku siswa tersebut. (Observasi di SMA Negeri 2 Rambatan, 18 Desember 2015). Evaluasi hasil belajar aspek afektif di SMA Negeri 2 Rambatan yaitu tingkah laku di luar kelas dan perilaku keagamaan. Kebanyakan siswa berperilaku baik dan melaksanakan kegiatan kegamaan di sekolah. Akan tetapi tidak dapat dipungkiri bahwa siswa yang berperilaku baik dan melaksanakan kegiatan kegamaan di sekolah hanya karena takut atau ingin dilihat baik di hadapan guru (Observasi di SMA Negeri 2 Rambatan, 18 Desember 2015).

Hasil analisis penilaian afektif pada mata pelajaran PAI di SMA Negeri 2 Rambatan yaitu dengan memberikan skor nilai dengan kategori sangat baik yaitu antara 81-100, baik antara 69-80, sedangkan yang kurang antara 40-68. Sebenarnya teknik penskoran dengan menggunakan angka tidak cocok untuk menentukan nilai afektif, karena untuk menganalisis hasil evaluasi dan menentukan nilainya cukup sulit. Sebaiknya guru menggunakan teknik penskoran menggunakan huruf, yaitu untuk nilai A: sangat baik, nilai B: baik dan nilai C: kurang. Nilai afektif ini juga bisa digunakan untuk memberikan tambahan terhadap nilai hasil tes yang kurang, contohnya ketika ada siswa yang mendapat nilai 6,5 , maka bisa ditambah nilai afektifnya dan disempurnakan menjadi 70 . 
Dari proses pelaksanaan evaluasi ranah afektif mata pelajaran PAI terdapat beberapa masalah yang menjadi perhatian peneliti, yaitu masalah konseptual dan masalah operasional. Masalah konseptual yaitu sulitnya menerapkan rambu-rambu tentang pelaksanaan evaluasi ranah afektif dari pemerintah dan dari Departemen Agama. Hal ini dapat dilihat dari beberapa soal ulangan akhir semester maupun dalam Ujian Nasional kebanyakan didominasi oleh aspek kognitif, padahal tujuan daripada Pendidikan Agama Islam adalah menekankan pada keutuhan dan keterpaduan antara ranah kognitif, afektif dan psikomotorik. Sedangkan untuk masalah operasional pelaksanaan evaluasi ranah afektif mata pelajaran PAI antara lain evaluasi memerlukaan banyak waktu, evaluasi afektif sulit karena berkaitan dengan perasaan siswa, dan tidak adannya kerja sama dalam evaluasi afektif. Waktu yang diperlukan untuk kegiatan evaluasi afektif tergolong banyak, karena harus mewancarai siswa satu persatu.

\section{KESIMPULAN}

Berdasarkan uraian di atas kesimpulan penelitian ini adalah (1) rumusan tujuan dari pelaksanaan evaluasi ranah afektif mata pelajaran PAI di SMA Negeri 2 Rambatan disesuaikan dengan mata pelajaran yang sudah diajarkan pada semester tersebut; (2) dari proses pelaksanaan evaluasi ranah afektif mata pelajaran PAI terdapat masalah berupa masalah konseptual seperti susahnya menerapkan rambu-rambu tentang pelaksanaan evaluasi ranah afektif dari pemerintah dan dari Departemen Agama; dan (3) masalah operasional seperti evaluasi memerlukaan banyak waktu, evaluasi afektif sulit karena berkaitan dengan perasaan siswa, dan tidak adanya kerja sama dalam evaluasi afektif.

\section{KEPUSTAKAAN ACUAN}

Anderson, L.W dan Krathwohl, D.R. (2010). Kerangka Landasan untuk Pembelajaran, Pengajaran, dan Assesmen. Yogyakarta: Pustaka pelajar

Arifin, Zainal. (2012). Evaluasi Pembelajaran. Bandung: PT. Remaja Rosdakarya

Arikunto, Suharsimi. (2013). Dasar-Dasar Evaluasi Pendidikan. Jakarta: PT. Bumi Aksara.

Beni, Ahmad Saebani. (2008). Metode Penelitian. Bandung: Pustaka Setia

BSNP. (2006). Panduan Penyusunan Kurikulum Tingkat Satuan Pendidikan Jenjang Pendidikan Dasar dan Menengah. Jakarta: BSNP

Fernandes, H.A.X. (1983). Affective Domain Assesment in Perspective. Jakarta: Badan Penelitian dan Pengembangan Pendidikan dan Kebudayaan. 
Gronlund, N.E dan Linn R.L. (1990). Sudijono, A. (1996). Pengantar Evaluasi Measurement and Evaluation in Pendidikan. Jakarta: PT Raja Grafindo Educational Objecives. New York: David Persada Mckay Company.

Lovat, Terence J. dan David L. Smith. (2003). Curriculum; Action on Reflection. Australia: Social Science Press.

Miller, M. David. Linn, Robert L. \& Norman E. Gronlund. (2009). Measurement and Assessment in Teaching. New Jersey: Pearson Education, Inc.

Patton, M. (1990). Qualitative Evaluation and Research Method. California: Sage Publication.

Print, Murray. (1993). Curriculum Development and Design. Australia: Allen \& Unwin.

_ (2011). Pengantar Evaluasi Pendidikan. Jakarta: Raja Grafindo Persada.

Worthen, B.R \& Sanders, J.R. (1987). Educational Evaluation. Alternative Approaches and Practical Guidelines. New York \& London: Longman Inc.

Zariah, Nurul. (2005). Metodologi Penelitian Sosial dan Pendidikan. Jakarta: Bumi Aksara 